This item was submitted to Loughborough's Research Repository by the author.

Items in Figshare are protected by copyright, with all rights reserved, unless otherwise indicated.

\title{
Lean approach in precast concrete component production
}

PLEASE CITE THE PUBLISHED VERSION

https://doi.org/10.1108/BEPAM-02-2018-0051

PUBLISHER

(C) Emerald

VERSION

AM (Accepted Manuscript)

\section{PUBLISHER STATEMENT}

This work is made available according to the conditions of the Creative Commons Attribution-NonCommercialNoDerivatives 4.0 International (CC BY-NC-ND 4.0) licence. Full details of this licence are available at: https://creativecommons.org/licenses/by-nc-nd/4.0/

\section{LICENCE}

CC BY-NC-ND 4.0

\section{REPOSITORY RECORD}

Ahmad, Suryani, Robby Soetanto, and Chris I. Goodier. 2019. "Lean Approach in Precast Concrete Component Production”. figshare. https://hdl.handle.net/2134/37050. 


\title{
LEAN APPROACH IN PRECAST CONCRETE COMPONENT PRODUCTION
}

\author{
Suryani Ahmad, Robby Soetanto, Chris Goodier \\ School of Architecture, Building and Civil Engineering \\ Loughborough University \\ United Kingdom
}

\begin{abstract}
Purpose - This study applied the lean approach to the reinforcement work process in the component production of industrialised building system precast concrete construction (IBSPCC). The primary aim of the research was to identify and eliminate previously overlooked non-value added (NVA) activities to enhance the efficiency of the production process.

Design/Methodology/Approach - Data were collected via a case study of six-storey precast concrete building. A mapping of the reinforcement work process was conducted based on observations using time study technique and time-lapsed video, complemented by semistructured interviews.

Findings - Through this application, several previously overlooked NVA activities, such as unnecessary inventory, excessive movement, and coordination issues, were identified. Production performance could be enhanced by implementing Just-in-Time, Kanban, and layout improvements, which would address NVA activities.

Research Limitation/Implication - Due to the complexity of the construction process, only specific process elements were observed. To map the complete process, comprehensive observation must be conducted from beginning to end, which, though worthy, would be very time and resource intensive.

Originality/Value - This paper focuses on strategies for improving the efficiency of the IBSPCC production process in Malaysian construction by developing a conceptual framework of the lean approach for the reinforcement work process. Certain aspects in the process such as layout and inventory need to be redesigned and simplified by minimising NVA activities.
\end{abstract}

Keywords Industrialised building system (IBS), precast concrete construction (PCC), nonvalue added (NVA) activity, lean approach, reinforcement work process, process improvement.

Paper type Case study

\section{Introduction}

Successful application of the lean approach within manufacturing has attracted significant attention from construction stakeholders wanting help to improve the flow of their processes, for example as part of an industrialised building system (IBS). The term IBS, as used in Malaysian construction industry, is defined as "a construction technique in which the components are manufactured in a controlled environment (on or off-site), transported, 
positioned and assembled into a structure with minimal additional site work" (CIDB et al., 2010). Different terms such as off-site, modern methods of construction (MMC), prefabrication and preassembly, are sometimes described as IBS, but there are important distinctions between them (Kamar et al., 2011). This IBS definition focuses on building with structural components (e.g. columns, beams and walls/panels); comprises six types of structural system (precast, steel, timber, formwork, blockwork and innovative system based on wall components). IBS public CIDB , must achieve a minimum of 70 points (IBS score), and based on an assessment of the structural systems (precast beam, column and steel), wall systems (e.g. glass, dry partition, block work and precast panel) and other simplified construction solutions. A higher score reflects a higher reduction of waste labour and cost.

Several comparative studies between IBSPCC) and conventional construction (CC) have revealed that IBSPCC can increase labour productivity, speed up construction, and increase quality. Nevertheless, most of these studies concentrated on the on-site assembly process. For example, Abdul Kadir et al. (2006) and Gunawan (2013), compared CC with IBSPCC and concluded that IBSPCC has the potential to improve labour productivity, shorten completion time, and increase process efficiency. Hanafi et al. (2010) discussed important factors influencing labour productivity in the assembly process, such as planning, scheduling, and availability of machinery. Apart from the assembly process, investigation on the component production of IBSPCC, namely reinforcement, formwork and concreting, appear to be scarce.

The application of the lean approach to off-site construction have shown evidence of improvement in construction process. Pasquire and Connolly (2002) examined the application of the lean approach to off-site manufacturing of pre-assembled buildings, resulting in significant reductions of labour, time and cost. They concluded that, the process improvement must stem from the organisation's aspiration, and realising the benefits for a continuous improvement is essential in the long run. Therefore, the fundamental of the lean approach is that continuous improvements must emerge from the processes and people, supported by long-term commitment from all stakeholders (Meiling, Backlund and Johnsson, 2012). The lean approach also contributes to the improvement of the environmental, social and economic aspects, particularly in promoting safer building techniques in modular construction (Nahmens and Ikuma 2012). With substantial benefits as discussed in the literature, it is hypothesized that the lean approach could help to improve the work processes of IBSPCC in Malaysia.

When exploring critical success factors, drivers and challenges, Mohd Noor et al. (2018), Yunus et al. (2017) and Nasrollahzadeh et al. (2016) concluded that the application of the lean approach is vital to improve the work process efficiency of IBS. However, the challenges occur due to a lack of guideline and differing stakeholders' perspective, which leads to misconceptions regarding lean. Jaafar and Mahamad (2012) claimed that Just-inTime (JIT) is a common practice within the delivery, inventory and production of IBSPCC components, with the demand schedule from the contractor as the determining factor for the production. However, they have not explicitly discussed the strategy of JIT application in precast concrete production for improving the overall IBS process.

The Malaysian construction industry still suffers from low productivity due to a lack of innovation and technology adoption in construction methods and a heavy reliance on unskilled labour (CIDB 2015). In addition, most of the work processes within IBSPCC production are still using similar techniques to $\mathrm{CC}$, with an exception that the components are produced in a precast manufacturing environment. For example, the cutting, bending and fixing of reinforcement is still labour intensive with minimal use of machinery for automation. Some unnecessary repetitions may also occur in IBSPCC production, hence creating NVA activities during the process. 
Therefore, this research focuses on the reinforcement work process, one of the upstream activities that is labour intensive, and comprises many sub-activities and movements. The lean approach was applied to improve the process via identification of NVA activities, which could potentially be minimised or eliminated. This study offers several main contributions. Firstly, the development of a process map informed by the lean approach permits optimisation of the IBSPCC work processes. Secondly, the study will increase understanding and awareness of the benefits of the lean thinking for production team. Enhanced understanding will create opportunities for improved communication and coordination of workflow, as well as flexibility to achieve continuous improvement within the IBSPCC work processes.

The following section discusses literature pertaining to the lean approach and the construction process before the research method adopted, (including a case study of the reinforcement work process and data collection techniques), is explained. This is followed by the analysis of the results and discussion regarding NVA activities. Strategies to develop a conceptual framework of the lean approach to help improve the understanding and hence efficiency of the process are then proposed, before final conclusions are drawn.

\section{Lean approach and construction process}

The idea of using IBS was initiated from the concept of manufacturing (Koskela 2000). Recurring processes had been noted in both IBS and manufacturing. Even though Ballard and Howell (1998) critiqued that construction is bespoke and has little in common with manufacturing, Egan (1998, p.18) claimed that the process of construction itself is repeated from one project to another. Indeed, up to $80 \%$ of inputs into buildings are repeated in the process, similar to the production line in manufacturing. For this reason, Egan (1998: 23) suggested that the construction industry applies the lean approach, mainly for improving productivity.

The lean approach focuses on customers, continuous improvement and quality through reduction of NVA activities, and integrated upstream and downstream processes, as part of the lean value chain (Liker and Morgan 2006). Removing NVA activities is the major goal in the lean approach (Emuze and Saurin 2016; Liker and Morgan 2006; Dunlop 2005). In fact, the lean approach does not concentrate on physical waste, but rather on the construction activities that generate inefficient use of equipment, workflow or labour in the construction process (Nikakhtar et al. 2015). The application of the lean approach promises substantial benefits especially reducing lead time which is the most important in the production (Ballard and Arbulu 2004)

The lean approach in PCC was experimented by Ballard et al. (2003) resulting in a substantial improvement in the production performance through the reduction of lead and cycle times. The study focused on remodelling the production line flow for precast shear walls, which resembles the process within the batch and queue theory (Diekmann et al. 2004) that assumes a high rate of machine utilisation. This is different from the IBSPCC production, which is more labour dependent. Although the improvement resulting from re-structuring the production cells covered the overall precast fabrication process, detailed reinforcement work process was not clearly investigated. Furthermore, production lead time is interdependent and occurs together with demand variability. Ko (2012) developed a lead time model and proposed two adjustments to the production schedule to reduce the impact of demand variability, namely starting fabrication later relative to delivery dates, and shifting production milestones towards the end of the production process. It was revealed that the adjustments permit variability without affecting the delivery dates as required by the customer. The study is limited to the production scheduling only and did not addressed physical work of the 
reinforcement work process of IBSPCC such as manpower usage, movement, production layout, and NVA activities. Nevertheless, the idea of lean explained in this experiment may be appropriate for the implementation in the planning of IBSPCC.

The classification of NVA activities was developed by Shingo (1989), who divided NVA activities in the production line into seven types, namely: i) overproduction, ii) waiting, iii) transportation, iv) processing, v) inventory, vi) defects, and vii) motion. Similarly, Ray et al. (2006) listed eight types of NVA activities by including viii) people that generate those activities, such as poor safety record, rework, overtime, and unscheduled break, to name a few. Amongst the types of NVA activity, Sutherland et al.(2007) mentioned that overproduction could be the major NVA activity in the production line because the resources spent on manufacturing turn into wasteful products, either they produce the product earlier or faster than it is required by demand. This leads to the other six NVA activities. However, Koskela et al. (2013), in line with Formoso et al. (2011), disagreed by claiming that overproduction is not a dominant NVA activity in construction. They mentioned that, making-do, referring to a situation where a task starts even when all the inputs required are not fully prepared (e.g. inadequate temporary facilities), has been named as the major NVA activity in construction. However, in IBSPCC, the process involves two major sub-processes; production and on-site assembly. It means dominant NVA activities in these two subprocesses perhaps differ from what is stated by Koskela et al. (2013), Formoso et al. (2011) and Sutherland et al. (2007). Hence, addressing NVA activities appears to be the most challenging task, mainly due to the various and complex work process found in the IBSPCC.

Many studies have examined NVA activities for the purpose of process improvement. For instance, Lee et al. (1999) studied how to identify and quantify NVA activities in the construction process, to address the inadequacy of tools for measuring NVA activities in the previous research. They proposed Construction Process Analysis (CPA) technique as an appropriate tool to identify NVA activities. However, the CPA is only appropriate for analysing highly repetitive processes, such as steel erection. Meanwhile, Al-Sudairi (2007) examined the applicability of lean principles to two simple construction processes, plastering and block laying, using process mapping and simulation. The performance increased by 21 and 50 percent for block laying and plastering processes respectively, because of the reduction of NVA activities and shorter cycle times. Larsson and Simonsson (2012) used value stream mapping to analyse the prefabrication process and revealed a reduction of complexity and 75 percent increase in speed, when compared to the CC. Further, AbbasianHosseini (2014) used simulation models to evaluate the effects of implementing the lean approach to bricklaying process. The study found that productivity increased more than 40 percent.

All the studies above focused on various construction processes with different techniques or tools to meet their objectives. However, research on how the concept of lean could be applied to improve the efficiency of reinforcement work process in IBSPCC has not been significantly undertaken. This study therefore intends to address this knowledge gap by developing a generic map of the reinforcement work process to represent the sequence of key activities, and to identify potential improvements. The main research question which this paper therefore addresses is:

What are the main strategies in the application of the lean approach that could help improve the reinforcement work process in IBSPCC? 


\section{Research Method}

This study included two research stages, exploratory and descriptive. The exploratory stage involved semi-structured interviews with practitioners, whereas the descriptive stage employed a case study strategy to obtain a comprehensive understanding of the reinforcement work process for IBSPCC (Denscombe, 2010). Here, it is essential to determine the unit of analysis beforehand, as a major entity that is being analysed (Trochim 2006). The unit of analysis is the reinforcement work process in the component production of IBSPCC. The case study was conducted in March 2017 and obtained from IBS manufacturer list from Construction Industry Development Board (CIDB in Malaysia) database. The IBS manufacturer must be registered with CIDB to be certified as IBS manufacturers (CIDB 2017). The selected IBS manufacturer had ten years of experience in IBSPCC, both in producing and assembling the components. The project selected was in the process of producing precast concrete components including columns and beams for a six-storey international school in Cyberjaya, which was classified as a medium rise building. In line with the research question above, in-depth observations of the sub-activities (cutting, bending, fabricate and placing) were undertaken during the fabrication of the reinforcement. All the information regarding techniques used is further explained in the next (data collection and results) sections. Figure 1 illustrates the adopted research method of embedding the lean approach into the reinforcement work process. The fieldwork observation was complemented by semi-structured interviews. 


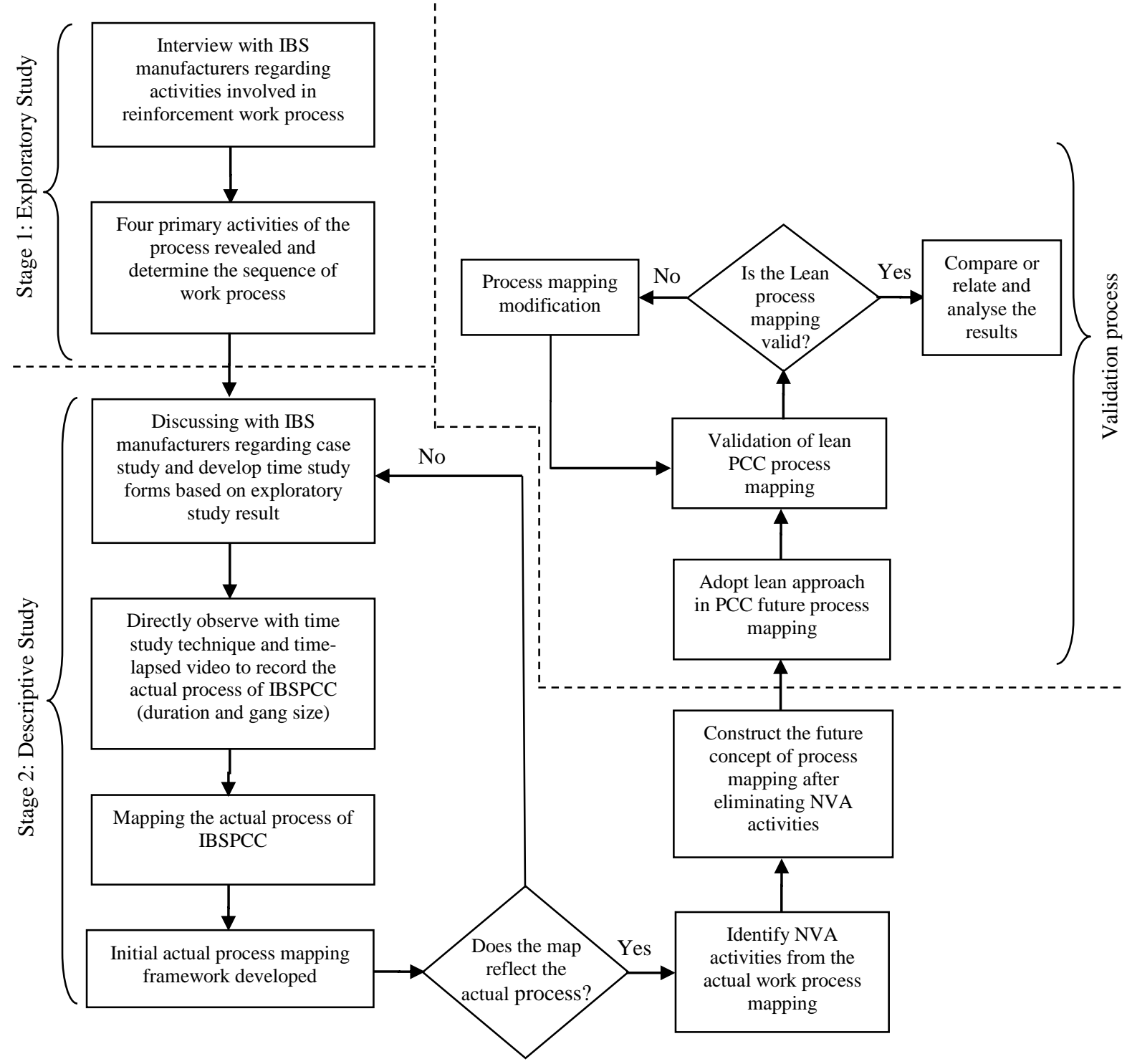

Figure 1 Research method process and adoption of the lean approach

\section{Data collection}

As part of the initial exploratory study, semi-structured interviews were conducted to gain insights regarding the case study and to help determine the research focus. The questions were designed to obtain information from practitioners regarding the existing work processes, including the sub-activities, labour usage and average duration for each activity. The criteria for selecting the practitioners were: i) experience of at least 5 years in construction, ii) registered as a CIDB qualified IBS manufacturer, and iii) currently involved in the IBSPCC project case study. This exploratory study identified primary activities which determined the sequence of the reinforcement work process.

The second stage, descriptive study (Saunders, Lewis and Thornhill, 2009) was conducted to describe the process in detail, and to identify any NVA activities. Two 
techniques, structured observation via time study and time-lapsed video observation, were incorporated into the fieldwork. Both investigated on-going activities at the beginning of the process, and detailed notes were recorded by the researcher for each predetermined activity, for example, cutting, bending, fabricating the steel bars and placing the cages. Hence, the duration and the number of workers required to complete the task were identified. Some studies (Abbasian-Hosseini et al. 2014; Dunlop 2004; Diekmann et al. 2004) have applied this technique to develop a standard time and output for productivity improvement in construction operations. However, these studies only focused on bricklaying, concreting, steel erection and pipe installation (not on the production of precast concrete components).

Time-lapsed video observations were conducted to record the whole process so that it could be reviewed later multiple times, and to highlight any NVA activities. According to Liu et al. (2014), Leicht et al. (2010) and Garcez et al. (2011), the use of video is more efficient in capturing information and offers the ability to review as many times as desired. Both structured observation with time study and time-lapsed video recording were performed simultaneously. Subsequently, detailed steps and durations pertaining to the reinforcement work process could be determined.

\section{Results and Discussion}

\subsection{The present state of process mapping}

The exploratory study established details of the four primary sub-activities, namely, i) cutting, ii) bending, iii) fabricating, and iv) placing, which provide a framework of the descriptive study (stage 2). Detailed data for each activity is depicted in Table 1 . The number of activities for the actual production process was initially 17, which were divided into two teams; steelwork with seven workers and concreter with two workers. During observations with the time study technique, several similarities between IBSPCC and CC were noted. For instance, bending and cutting machines were standard equipment for both methods. The activities of cutting, bending, and fabricating were conducted mostly in the same way in both IBSPCC and CC. The number of components produced in the IBSPCC production was based on daily rate and was constrained by the quantity and availability of moulds.

In this case study, ten beams and three columns of moulds were used. As portrayed in Table 1, the process began with manually carrying (item 2) the steel bars from open storage (Item 1) to the cutting area (item 3), with an average time of 15 minutes to cut the steel bars per component (i.e. beam). Next, the cut steel bars were delivered to the bending area (item 4) and spent 15 minutes to complete the bending process. These two activities involved two workers from the steelwork team. They just cut and bent the steel bars as much as they could in a day; the fabrication was not based on when it is needed in the work programmed.

After this, the bent steel bars were stored (item 5) until they were delivered to the fabrication area. The workers responsible for fabricating the steel bars had to move to the storage area and carry them on their shoulders to the fabrication area. At this area, the steel bars were placed before use (item 6 and 7). During the fabrication process, five workers at three areas fabricate the cages with two of them consisting of two workers each and one in the remaining area. All five workers worked concurrently (items 8, 9 and 10). The average duration for each gang to complete a cage for an RC component was 45 minutes. All these average times depended on the complexity of the design, the size, and the dimension of the steel bars. Like the steps in items 3 and 4, the work in items 8,9 and 10 does not follow the predetermined timeframe of the whole production team, but it is solely based on the 
scheduled task of steelwork team. Thus, 'push' system is predominant in the prefabrication process.

Later, the completed cages were inspected (item 11) by the supervisor to confirm correct size and tightness. In the case of any major problem related to accuracy of the fabricated cages, a rectification was demanded (item 12) prior to be placed in storage area and ready for placing in the mould. Other fabricated cages, which were located at the open storage area (item 13), were scheduled to be placed into the mould (item 14), in either the next or two days later. After 24 or 48 hours, the cages were lifted (item 15) using a mobile crane to install a spacer chair (item 16) and ducting pipes (if required), immediately after the cages were placed into the mould (item 17). The mould had been prepared, cleaned, and oiled beforehand. Finally, concreting pour resumed on the same day. Overall, seven workers from steelwork team were involved in completing items 1 until 14. Only two workers from the concreting teams were needed to complete items 15 to 17 . In this study, the number of activities performed in the reinforcement process was 17 with total working time of 540 minutes ( 9 hours) including idle time (morning, lunch, and afternoon breaks). The total of effective time (excluding idle time), was only 420 minutes per day for workers to perform their tasks.

The analysis of the process identified the NVA activities as follows:

\section{a) Unnecessary Inventory}

Based on the observation and records, the steelwork team produced more than what was required in a day most of the time. This resulted in a surplus quantity of both cut and bent steel bars and fabricated cages, as they were produced a long time prior to when they were needed. In a typical 420 minutes working day, each worker spent an average of 15 minutes cutting steel bars, whilst the other spent about 15 minutes to bend them, for a set of beam components. They could complete up to 28 sets of beam components in a day. Meanwhile, the maximum sets of cut and bend steel bars used in a day had been only ten. This reflects some ineffective 180 minutes per day spent by the workers to cut and bend the steel bars, which were not used on the same day.

Table 1 (items 8, 9 and 10) shows three areas allocated for fabrication work. Five workers in three teams/areas fabricated the component concurrently, which only took 45 minutes for one team (in one area) to complete a set. At the end of the day, they had produced approximately 27 cages of beam. Meanwhile, based on the production for daily programme, the maximum concrete casting was only for 10 cages for a day. This leads to a surplus of 18 sets of cut and bent steel bars, and 17 cages, which were not used on the same day. Nevertheless, 180 minutes were spent for ineffective tasks by both fabricating teams 1 and 2 . On the other hand, fabricating team 3 spent ineffective task for a whole day, whereby the completed cages were stored for at least 1 day before being use. Such tasks caused unnecessary inventory in cut-and-bent storage, including fabrication. Overall, they contribute to NVA activities, such as increased storage space, unorganised stacking, double handling, as well as long waiting time for fabrication and placing it into the mould as stated in Table 1 (classification of NVA activities). Furthermore, this practice compromises steel quality as storage in the open area for some time causes corrosion.

\section{b) Excessive movement}

Due to limited automation, the reinforcement work process of both the IBSPCC and CC methods were highly dependent on operatives. This results in no obvious difference in workflows, number of workers, machineries and equipment used in both methods. During the 
observation, the activity of carrying tools or materials by two workers could be considered as necessary although they do not add any value. Furthermore, the time lapsed video observation shows that, frequent trips of a worker (for 19 trips with an average time of 18 minutes per return trip) are considered as excessive movements. These movements occurred to set up the next cage fabrication area after one was completed. Such movements were necessary due to an inefficient yard layout. Also, excessive movements may have negative impacts such as injuries or disruption to other teams as shown in Figure 3. Nonetheless, this recurrent NVA movement could be reduced or eliminated if an improved layout and/or method of carrying the materials, such as the use of gantry crane (which can carry in a bundle) for moving steel bars to the fabrication area.

c) Coordination

Although a sequence of components to be produced existed, insufficient coordination was observed in terms of scheduling and the timeframe between steelwork and production team. This resulted in the 'push' instead of the 'pull' system in the production process (as in Kanban). The 'push' system differs from the 'pull' system in that the production for the former is made to stock by the upstream supply regardless of demand from downstream activities, whilst for the latter, it is made to order or based on actual demands by the downstream activities (Diekmann et al., 2004). Although 'push' system seems beneficial in terms of uninterrupted supply to downstream team, a large storage space was required at every step. 
Table 1 Overall reinforcement process based on duration and gang size per component

\begin{tabular}{|c|c|c|c|c|c|}
\hline Item & Sub-Activities & $\begin{array}{l}\text { Duration per } \\
\text { component } \\
(\text { min })\end{array}$ & Workers & Remarks & NVA classification \\
\hline 1 & Open Storage & - & \multirow{3}{*}{1} & For uncut steel bars & \multirow{4}{*}{ Unnecessary inventory } \\
\hline 2 & $\begin{array}{l}\text { Manually carrying the steel bars to the cutting } \\
\text { area }\end{array}$ & - & & The distance to cutting area is nearer. & \\
\hline 3 & Cutting steel bars & 15 & & \multirow{2}{*}{$\begin{array}{l}\text { Both activities of cutting and bending } \\
\text { referred to steelwork schedule not as } \\
\text { production schedule. }\end{array}$} & \\
\hline 4 & Bending steel bars & 15 & 1 & & \\
\hline 5 & Placement and storage of steel bars (Storage 1) & - & & $\begin{array}{l}\text { Cut and bended of the steel bars that are } \\
\text { not scheduled to be used immediately. }\end{array}$ & $\begin{array}{l}\text { Lack of integration in } \\
\text { communication and } \\
\text { coordination }\end{array}$ \\
\hline 6 & $\begin{array}{l}\text { Manually carrying the steel bars to fabrication } \\
\text { area }\end{array}$ & \multirow[t]{2}{*}{18} & & \multirow[t]{2}{*}{$\begin{array}{l}19 \text { return trips (from bending area to } \\
\text { fabrication area) }\end{array}$} & \multirow[t]{2}{*}{ Excessive movement } \\
\hline 7 & Placed nearby fabrication area & & & & \\
\hline 8 & Fabrication 1 & 45 & 2 & \multirow{3}{*}{$\begin{array}{l}\text { Each fabrication area produced } 9 \text { sets of } \\
\text { completed reinforcement cages, hence } \\
\text { totalling up to } 27 \text { sets of cages. }\end{array}$} & \multirow{3}{*}{$\begin{array}{l}\text { Lack of integration in } \\
\text { communication and } \\
\text { coordination, } \\
\text { Unnecessary inventory }\end{array}$} \\
\hline 9 & Fabrication 2 & 45 & 2 & & \\
\hline 10 & Fabrication 3 & 90 & 1 & & \\
\hline 11 & Inspection & 10 & & QA and QC supervision (production team) & - \\
\hline 12 & Rework & - & & $\begin{array}{l}\text { Adjustment ( } 24 \text { hours), if required. } \\
\text { Not a daily problem, but rectification is } \\
\text { demanded upon occurrence. }\end{array}$ & - \\
\hline 13 & Placement at storage (Storage 2) & \multirow[b]{2}{*}{1440 or 2880} & \multirow[t]{2}{*}{-} & \multirow[t]{2}{*}{ Long period of waiting. } & \multirow[t]{2}{*}{ Unnecessary inventory } \\
\hline 14 & Waiting for placement & & & & \\
\hline \multicolumn{2}{|c|}{ Total number of Steelwork Team members } & & 7 & & \\
\hline 15 & Lifting & & \multirow{3}{*}{2} & \multirow{2}{*}{$\begin{array}{l}\text { The operation for the next day is to place } \\
\text { the fabricated cage into the steel mould }\end{array}$} & \multirow[b]{2}{*}{-} \\
\hline 16 & $\begin{array}{l}\text { Tightening, as well as placing spacer chair and } \\
\text { ducting pipes }\end{array}$ & 6 & & & \\
\hline 17 & Placing to the mould & 4 & & Installation of the other side of the mould. & - \\
\hline \multicolumn{2}{|c|}{ Total number of Concreting Team members } & & 2 & & \\
\hline
\end{tabular}




\subsection{Generic map for a lean process}

Upon identifying the NVA activities, several strategies are explained to improve future work process by adopting the lean approach, as follows.

\section{a) Inventory management control}

Raw materials, regardless uncut and unbend or cut and bend, require a very large space for storage. Excessive inventory due to poor management, as well as lack of coordination and communication, disrupts the flow of material and information. In this case, more transparency is required in communication and coordination between casting and steelwork teams to reduce inventory usage. Hence, to improve inventory management, the Just-In-Time (JIT) (Polat and Arditi 2005) that keeps storage at a minimum level, along with the Kanban system to control flow (Deffense and Cachadinha 2011), should be adopted. By considering initial cutting and bending activities of reinforcement work process, it is suggested that two teams are required at the fabrication yard as illustrated in Figure 2. Since the casting team can only cast not more than ten components in a day, it is important for the steelwork team to produce the same to prevent excessive inventory. In preventing short supply to the casting team, in the morning they should use the five cages fabricated from the day before and in the afternoon, they should use the five from the morning. The next five cages fabricated in the evening will be used for the next day. This cycle should continue every day. However, to make this work, the steelwork team is required to prepare an extra five sets at the initial phase of the cycle. This will enable successful implementation of the JIT concept with Kanban. Kanban triggers signal to the need to move cages to the production. Nevertheless, the steelwork team must label each fabricated cage as first in, first out for stacking purposes. In this process, the fabricated cages can be better organised with minimal amount in the inventory.

\section{b) Better coordination and communication}

A good start for a project before undertaking the tasks is to establish interdependencies for all activities and to demonstrate necessary prerequisites for coordination (Sandberg and Bildsten 2011). The casting team should provide all important information and be transparent to the steelwork team, especially regarding the total number of columns and beams to be produced, duration (start and completion time), limited amount of mould available, as well as target output daily, weekly or monthly. In this case study, as only ten beam-moulds were available, the manager should inform the steelwork team that they can only produce a maximum of ten beams in a day. Based on this information, the steelwork team should manage the activities of cutting, bending, and fabricating only for the required sets. With such coordination and communication, the consistency between upstream cutting and bending activities and downstream fabrication and casting activities generates a potential solution to unnecessary inventory, aside from improvement of continuous workflow throughout the values stream. A continuous workflow ensures synchronisation between casting team and steelwork team at an optimum rate.

\section{c) Layout improvement}

The reinforcement work process still very much depends upon the labour force. Thus, it is quite difficult to eliminate movement of workers, especially when 90 percent of the work 
demands human interaction. As presented in Figure 2, the actual layout of fabrication yard required movements of worker from the storage area to the fabrication area. This situation generates excessive movement due to inefficient layout arrangement. The vertical positioning of the three fabrication yards creates no uninterrupted movement from and to the storage area. One of which, from fabrication area 2 to storage and vice versa would have to go through fabrication area 1. Hence, the best way to solve the excessive movement is to rearrange the fabrication layout, as illustrated in Figure 2. With elimination of fabrication area 3 from the process, the horizontal positioning is proposed, where the flow is more direct and shorter from the fabrication area to the storage area, without any interruption. Yet, the need to use other equipment, such as wheel barrow to carry the links in large quantities, is helpful, instead of frequent movements made from one work station to another, which ultimately waste operative time.

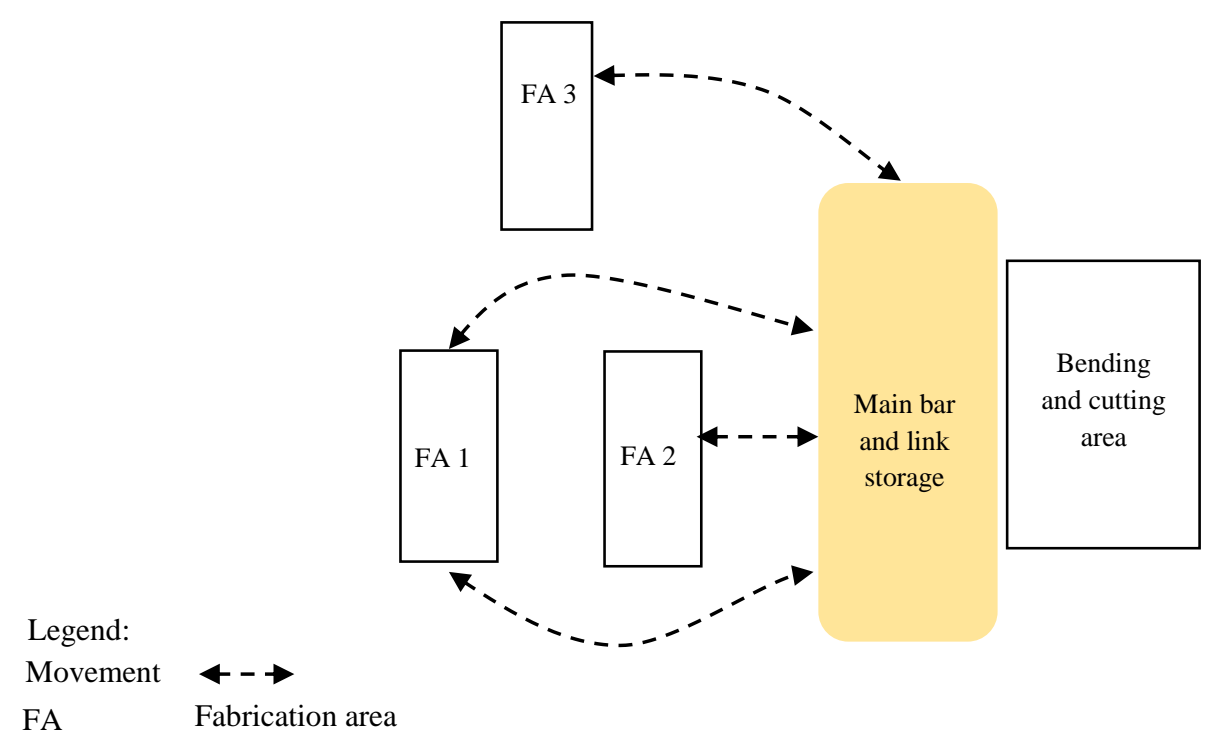

Actual layout of fabrication yard

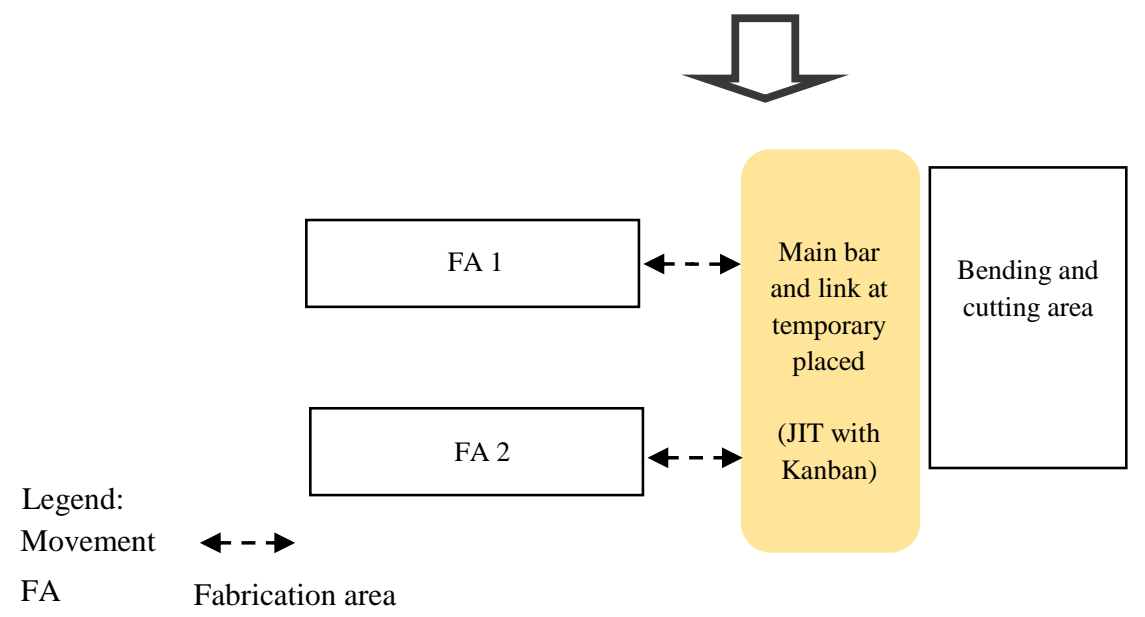

New Fabrication Yard Layout

Figure 2 Actual and new fabrication yard layout upon adopting the lean approach 
Figure 3 presents a generic map of reinforcement work process, developed based on the lean approach. Instead of the 14 activities listed in the existing process, the number of VA activities is five, whereas non-value-added but required (NVAR) activities are three, hence a total of eight activities. In addition, several strategies and changes have been proposed to enhance the process. Several NVAR activities, such as temporary placement, inspection, and storage, are required in the process mapping. Additionally, the JIT concept with Kanban, for inventory management and control to implement a 'pull' system, generates tasks based on actual demand. Besides, the continuous flow ensures synchronisation of information between upstream and downstream activities, which reflects a smooth coordination throughout the process. Due to that, tasks of cutting, bending, and fabricating are performed at the same rate with the concreting team schedule, based on the amount of available moulds.

The amount of bent steel bars (i.e. main steel bars and links) will be placed at the temporary area, where workers can take and carry the main steel bars and links directly to the fabrication area. The bending and cutting are undertaken only based on production team's daily program, where only ten sets are required in a day. The re-arrangement of fabrication yard layout, which directly distributes temporary place to fabrication area 1 and 2 , will permit smoother workflow without any interruption, and reduces excessive movement. Undeniably, there will still be additional fabrication cages, especially when the concreting team fails to cast ten components in a day. Nonetheless, the amount left at the storage can be maintained at a minimum level. The idea of consistently having few additional fabricated cages (only five cages daily) seems relevant to avoid overproduction. The number of workers can be reduced from seven to five, where the person in-charge of cutting also can be deployed for fabricating the components. Thus, ten fabricated cages, as scheduled by the concreting team, can be placed in the mould on the same day. 


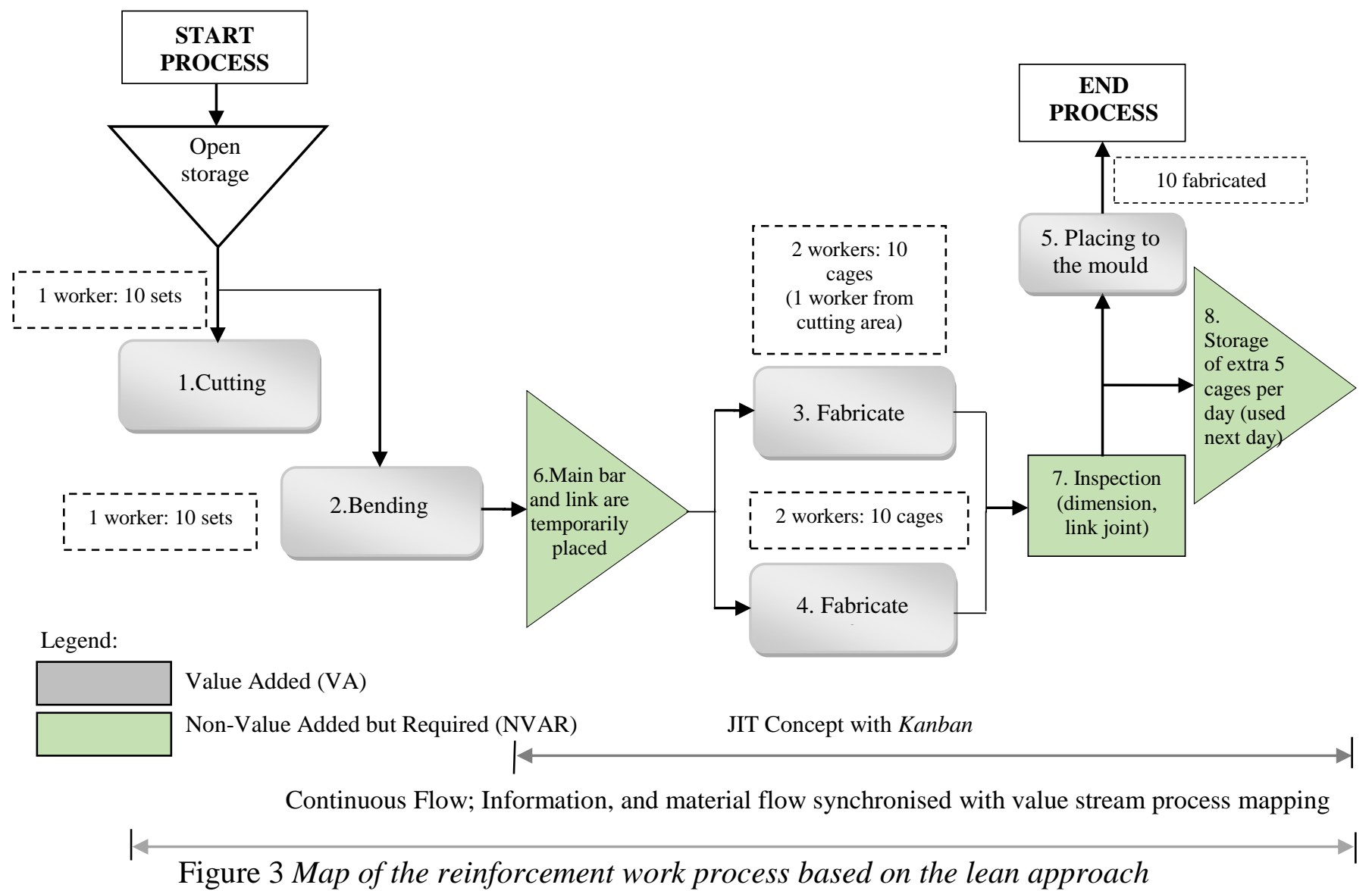

Figure 3 Map of the reinforcement work process based on the lean approach

\section{Conclusion}

This research has successfully identified and suggested the elimination of NVA activities in the reinforcement work process in IBSPCC production in Malaysia. The research showed that the adoption of the lean approach could enhance the efficiency of the process by identifying the previously overlooked NVA activities. It resulted in a reduction of workers and unnecessary inventory by rearranging the production layout and reducing excessive movements, which were considered as the most important modifications required in this case study. In practice, a generic map of the reinforcement work process using the lean approach can increase productivity. The adoption of the lean approach can also generate awareness and knowledge regarding lean principles amongst the production team. This awareness and understanding help enhance the ability of the production team to distinguish between VA and NVA activities in the work process, thus enabling the production team to address NVA activities more efficiently.

The application of lean tools and techniques, such as JIT with Kanban, and continuous flow, can support the work process in IBSPCC production. The implementation of the lean approach could help IBS manufacturers and contractors to improve the performance of their work processes. They could begin by providing training to their production teams, restructuring their work processes, and revising their standard operating procedures. The preliminary findings presented in this paper could also potentially be tested in another IBSPCC projects in collaboration with CIDB and IBS stakeholders. In order to adopt the lean approach successfully, it is critical that an organisation revisit and realign their vision, 
strategies and underpinning culture of continuous improvement at all levels. It also requires long-term, high level commitment from all within an organisation.

There are limitations to this research, however. The case study as presented here, for example, only investigates the reinforcement work process. IBS construction, however, involves other related work processes, which may create different NVA activities depending on the nature of the project. Future research could be conducted using the same method for other work processes, for example for precast mould construction/erection, concreting and on-site assembly. All the processes involved could be integrated through an overall IBS process framework to better represent, analyse and understand a holistic IBS system approach.

\section{Acknowledgment}

The authors gratefully acknowledge the following organisations for their contributions and support of this research; Construction Industry Development Board (CIDB) Malaysia and certified IBSPCC manufacturers. Appreciation also goes to Ministry of Education, Malaysia and Universiti Teknologi Mara (UiTM), Malaysia for the financial support in the form of scholarship to the author.

\section{References}

Abbasian-Hosseini, S.A., Nikakhtar, A., and Ghoddousi, P. (2014),"Verification of lean construction benefits through simulation modeling: A case study of bricklaying process". KSCE Journal of Civil Engineering. 18 (5), pp. 1248-1260.

Abdul Kadir, M., Lee, W., Jaafar, M., Sapuan, S., and Ali, A.A.A. (2006),"Construction performance comparison between conventional and industrialised building systems in Malaysia", Structural Survey, 24 (5), pp. 412-424.

Al-Sudair, A.A. (2007),"Evaluating the effect of construction process characteristics to the applicability of lean principles", Construction Innovation. 7 (1), pp. 99-121.

Ballard, G. and Arbulu, R. (2004),"Making Prefabrication Lean", In: Proceeding $12^{\text {th }}$ Annual Conference of the International Group for Lean Construction, Helsingør, Denmark,

Ballard, G., Harper, N., and Zabelle, T. (2003),"Learning to see work flow: an application of lean concepts to precast concrete fabrication", Journal of Engineering, Construction and Architectural Management, 10 (1), pp. 6-14.

Ballard, G. and Howell, G. (1998),"Shielding Production: Essential Step in Production Control", Journal of Construction Engineering and Management. 124 (1), pp. 11-17.

CIDB (2010),"Manual For IBS Content Scoring System (IBS Score) CIS 18: 2010", $3^{\text {rd }}$ Edition, Perpustakaan Negara Malaysia Cataloguing, Malaysia.

CIDB (2015),"Construction Industry Transformation Programme 2016 - 2020", Construction Industry Development Board, Malaysia.

CIDB, MPC, REHDA, and CREAM, (2010),"An Introduction of Industrialised Building System Manual for Developer", CIDB, Malaysia. 
Deffense, J. and Cachadinha, N.,(2011),"Lean Production in the Precast Concrete Components' Industry", In: $19^{\text {th }}$ International Group Lean Construction, Lima, Peru, pp. $557-567$.

Denscombe, M. (2010),"The Good Research Guide : for small-scale social research projects", $4^{\text {th }}$ Edition, Open University Press.

Diekmann, J, Krewedi, M., Joshua, B., Stewart, T., and Won, S. (2004),"Application of Lean Manufacturing Principles to Construction", The Construction Industry Institiute, The University of Texas.

Dunlop, P.G.(2005)," Investigation, modelling and planning of stochastic concrete placing operations", Unpublished Thesis, University of Edinburgh.

Egan, J.(1998),"Rethinking Construction the Report of the Construction Task Force", Department of Trade and industry.

Emuze, F. and Saurin, T.(2016),"Waste in Construction : Concepts and Types", In: F. Emuze and T. Saurin, eds. Value and Waste in Lean Construction. p. 1.

Formoso, C.T., Sommer, L., Koskela, L. and Isatto, E.L.(2011),"An Exploratory Study on the Measurement and Analysis of Making-Do in Construction Sites", In: $19^{\text {th }}$ Annual Conference of the International Group for Lean Construction, Lima, Peru, pp. 236-246.

Garcez, A., Duarte, R. and Eisenberg, Z.(2011)," Production and analysis of video recordings in qualitative research", Educação e Pesquisa. 37 (2), pp. 249-261.

Gunawan, I.(2013), ,Construction Productivity Analysis of Pre- Cast and Conventional CastIn-Situ Projects A Case Study in Malaysia", Construction Engineering, 1 (2), pp. 26-36.

Hanafi, M.H., Khalid, A.G., Razak, A.A., and Abdullah, S.(2010)," Main Factors Influencing Labour Productivity of the Installation of on-Site Prefabricated Components", International Journal of Academic Research. 2 (6), pp. 139-147.

Kamar, K.A.M., Hamid, Z.A., Azman, M.N.A., and Ahamad, M.S.S. (2011)," Industrialized Building System (IBS): revisiting issues of definition and classification", International Journal of Emerging Science, 1, pp. 120-132.

Ko, C.H. (2012),"Arranging Precast Production Schedules Using Demand Variability", In: $20^{\text {th }}$ Annual Conference of the International Group for Lean Construction, San Diego, USA.

Koskela, L. (2000)," An Exploration towards a Production Theory and its Application to Construction", Technical Research Centre of Finland.

Koskela, L.J., Bølviken, T., and Rooke, J. (2013), " Which are the wastes of construction?", In:12 th Annual International Group for Lean Construction, Helsingør, Denmark.

Larsson, J. and Simonsson, P. (2012),"Decreasing Complexity of the On-Site Construction 
Process Using Prefabrication: a case study", In: 20 th Annual Conference of the International Group for Lean Construction, San Diego,USA.

Lee, S.H., Diekmann, J.E., Songer, A.D., and Brown, H. (1999),"Identifying Waste: Application of Construction Process Analysis", In: $7^{\text {th }}$ Annual Conference of the International Group for Lean Constrction, University of California, Berkeley, CA, USA.

Leicht, R.M., Hunter, S.T., SALUJA, C., and Messner, J.I.(2010),"Implementing Observational Research Methods to Study Team Performance in Construction Management," Journal of Construction Engineering and Management, 136 (1), pp. 7686.

Liker, J. and Morgan, J.M. (2006)," The Toyota Way in Services: The Case of Lean Product Development", Academy of Management Perspectives. 20 (2), pp. 5-20.

Liu, J, Shahi, A., Haas, C.T., Goodrum, P., and Caldas, C.H. (2014),"Validation Methodologies and Their Impact in Construction Productivity Research. Journal of Construction Engineering and Management, 140 (10), pp. 1-10.

MEILING, J., BACKLUND, F., and JOHNSSON, H., 2012. Managing for continuous improvement in off-site construction: Evaluation of lean management principles. Engineering, Construction and Architectural Management. 19 (2), pp. 141-158.

Mohd Noor, S., Abdullah, A., Yunus, R., and Nagapan, S.(2018)," Insights into the Adoption of Lean Management in Industrialised Building System (IBS) implementation :The Drivers and Challenges. International Journal of Engineering and Technology. 7 (3.23), pp. 21-31.

Nahmens, I. and Ikuma, L.H., (2012)," Effects of Lean Construction on Sustainability of Modular Homebuilding. Journal of Architectural Engineering, 18 (2), pp. 155-163.

Nasrollahzadeh, T., Marsono, A.K., and Tap, M.M. (2016)", Critical Success Factor for Industrialized Building System Process Protocol Map by Lean Construction management", Journal of Civil \& Environmental Engineering, 06 (05).

Nikakhtar, A., HosseinI, A.A., Wong, K.Y., and Zavichi, A. (2015),"Application of lean construction principles to reduce construction process waste using computer simulation: a case study", International Journal of Services and Operations Management, 20 (4), p. 461.

Pasquire, C.L. and Connolly, G.E.(2002),"Leaner construction through off-site manufacturing. In: Proceedings $10^{\text {th }}$ of the International Group of Lean Construction Conference, Gramado, Brazil. pp. 1-13.

Polat, G. and Arditi, D. (2005.),"The JIT materials management system in developing countries", Construction Management and Economics. 23 (7), pp. 697-712.

Ray, B., Ripley, P., and Neal, D. (2006)," Lean Manufacturing: A Systematic Approach to Improving Productivity in the Precast Concrete Industry. Precast-Prestressed Concrete Institute Journal, pp. 2-11. 
Sandberg, E. and Bildsten, L. (2011),"Coordination and waste in Industrialised housing", Construction Innovation. 11 (1), pp. 77-91.

Saunders, M., Lewis, P., and Thornhill, A. (2009)," Research Methods for Business Students, $5^{\text {th }}$ edition, Pearson Education Limited. England: Prentice Hall.

Shingo, S. (1989)," A Study of the Toyota Production System from an Industrial Engineering viewpoint", Revised Ed. Cambridge, Massachusetts and Norwalk, Connecticut: Productivity Press.

Sutherland, J., Street, T., and Bennett, B. (2007)," The Seven Deadly Wastes of Logistics : Applying Toyota Production System Principles to Create Logistics Value", Center for Value Chain Research. pp. 1-9.

Yunus, R., Mohd Noor, S.R., Abdullah, A.H., Nagapan, S., Abdul Hamid, A.R., Ahmad Tajuddin, S.A., and Mat Jusof, R.(2017),"Critical Success Factors for Lean Thinking in the Application of Industrialised Building System ( IBS )", In: International Research and Innovation Summit (IRIS). pp. 1-8. 